\title{
"The role of corporate governance in debt and dividend policies: case of Slovakia"
}

\begin{tabular}{|c|c|}
\hline AUTHORS & $\begin{array}{l}\text { Hussam Musa (Dttp://orcid.org/0000-0002-4492-8770 } \\
\text { R http://www.researcherid.com/rid/C-9944-2019 } \\
\text { Frederik Rech } \\
\text { Zdenka Musová (D https://orcid.org/0000-0002-1067-8291 }\end{array}$ \\
\hline ARTICLE INFO & $\begin{array}{l}\text { Hussam Musa, Frederik Rech and Zdenka Musová (2019). The role of corporate } \\
\text { governance in debt and dividend policies: case of Slovakia. Investment } \\
\text { Management and Financial Innovations, 16(2), 206-217. } \\
\text { doi:10.21511/imfi.16(2).2019.18 }\end{array}$ \\
\hline DOI & http://dx.doi.org/10.21511/imfi.16(2).2019.18 \\
\hline RELEASED ON & Monday, 10 June 2019 \\
\hline RECEIVED ON & Saturday, 11 May 2019 \\
\hline ACCEPTED ON & Thursday, 30 May 2019 \\
\hline LICENSE & $\begin{array}{l}(c) E Y \\
\text { This work is licensed under a Creative Commons Attribution } 4.0 \text { International } \\
\text { License }\end{array}$ \\
\hline JOURNAL & "Investment Management and Financial Innovations" \\
\hline ISSN PRINT & $1810-4967$ \\
\hline ISSN ONLINE & $1812-9358$ \\
\hline PUBLISHER & LLC "Consulting Publishing Company "Business Perspectives" \\
\hline FOUNDER & LLC "Consulting Publishing Company "Business Perspectives" \\
\hline
\end{tabular}

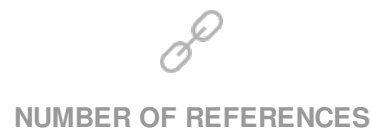

40

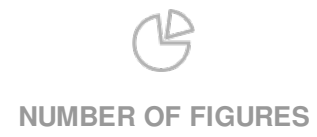

0

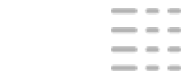

NUMBER OF TABLES

6

(C) The author(s) 2023. This publication is an open access article. 


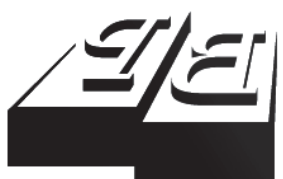

BUSINESS PERSPECTIVES

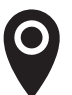

LLC "CPC "Business Perspectives" Hryhorii Skovoroda lane, 10, Sumy, 40022, Ukraine

www.businessperspectives.org

Received on: $11^{\text {th }}$ of May, 2019 Accepted on: $30^{\text {th }}$ of May, 2019

C) Hussam Musa, Frederik Rech, Zdenka Musová, 2019

Hussam Musa, Ph.D., Prof., Ing., Faculty of Economics, Matej Bel University in Banska Bystrica, Slovakia.

Frederik Rech, Bc., Faculty of Economics, Matej Bel University in Banska Bystrica, Slovakia.

Zdenka Musová, Ph.D., Doc. Ing. Faculty of Economics, Matej Bel University in Banska Bystrica, Slovakia.

\title{
THE ROLE OF CORPORATE GOVERNANCE IN DEBT AND DIVIDEND POLICIES: CASE OF SLOVAKIA
}

\begin{abstract}
Do good corporate governance practices affect the amount of intermediated debt used by corporations and their dividend payout decisions? This study addresses the direct effects of corporate governance practices on both the indebtedness and the dividend pay-outs in corporations listed on the Bratislava Stock Exchange in 2015-2017 in Slovakia. Because of the relatively weakly developed stock market, the hypothesis is set only to found whenever there is a correlation between those variables. For analyzing the data, Spearman's rank correlation was used because of the absence of normal distribution. Furthermore, authors adjusted the data set specifically in both cases to reflect more precisely the situation and increase the significance of the models. The most important result of this paper is the finding that the application of the corporate governance principles affects financial decisions of companies. There is a correlation between the responsible application of corporate governance principles and the total debt of companies. Also, there is a correlation between the responsible application of corporate governance principles and the amount of dividends paid to shareholders.
\end{abstract}

\section{Keywords}

\section{JEL Classification}

corporate governance, dividend policy, debt policy, Bratislava Stock Exchange, Slovakia

\section{INTRODUCTION}

The term corporate governance and its everyday usage is a new phenomenon that appeared in the last decades. The basic theories that influenced corporate governance include a variety of areas including finance, economics, accounting, law or management. The importance of corporate governance is growing largely due to the positive impact on the economy as a whole (Elbadry, 2010).

Good corporate governance practices became undoubtedly very important not only in terms of financial decision making, but also corporate performance, social responsibility, the economy as a whole, corporate management's areas and many others. Musa et al. (2018) present the following positive impacts of good corporate governance practices on the corporate management's areas:

- better access to the company to the external funding sources. Access to the funding sources stimulates higher investments, higher growth and the creation of new jobs;

- lowering the costs of capital and related higher company valuation; company's attractiveness for investors will increase, which leads to growth and higher employment; 
- improvement of operational performance owing to better source allocation and more effective governance, which creates wealth in general;

- better relations with all company's stakeholders - responsible implementation of corporate governance principles can generally minimize the occurrence of financial crises, which imply economic and social costs.

The relationship between corporate governance and its role in financial decision making is widely researched by many authors. From financial decision making, we chose two specific fields, namely debt and dividends. Debt is a very useful tool for corporations and good corporate governance practices can affect the amount of indebtedness (Day \& Taylor, 2004; Funchal et al., 2008; Chen et al., 2010; Musa et al., 2015; Ghouma et al., 2018). Dividends are one way of giving a return on investment to shareholders (Silva et al., 2004) and the decision of paying dividends, from the viewpoint of corporate governance, seems to vary in countries with different shareholder rights (La Porta et al., 2000; Adjaoud \& Amar, 2010; Chang et al., 2018).

In this paper, first, the importance of debt and dividends from the corporate governance point of view is described and then some evidence on the direct effects of good corporate governance on those variables is presented. The aim of the paper is to find out whenever there is a correlation between corporate governance and financial decision making processes as debt and dividend policies. Our primary research took place in Slovakia in the years 2015-2017. The subjects of this research were corporations listed on the Bratislava Stock Exchange - 61 corporations in 2015, 59 corporations in 2016 and 59 corporations in 2017. This research has followed on the previous investigation of the topic conducted in 2012-2013 (Musa et al., 2015).

The authors have chosen the following logical structure of the paper. In the Introduction, intentions of the authors are briefly outlined. Section 1 presents the relevant literature review about corporate governance and financial decision-making process, debt policy and dividend policy using a great variety of relevant secondary data. The next section explains the suggested research methodology. Section 3 is dedicated to primary research and its results. The obtained findings are also summarized in Conclusion.

\section{THEORETICAL BACKGROUND}

In this section, we present the relevant literature review regarding the impact of corporate governance on debt and dividend policies. First, we give an brief view on corporate governance, followed by work that relates firm-level corporate governance to debt and dividend policies. Finally, we develop our hypotheses based on secondary data analysis and our findings.

\subsection{Corporate governance and financial decision making}

Countries are starting to realize that sound corporate governance is, from a broader viewpoint, critical to economic and social progress, as well as a source of competitive advantage, from a briefer viewpoint (Mura et al., 2017). Increasingly, indi- vidual investors, funds, banks, and other financial institutions base their investment decisions not only on conventional investment strategies, but also on the company's reputation and governance (Kliestik et al., 2018; Blendinger \& Michalski, 2018). With globalization, there is even a bigger need for sound governance for firms to attract both domestic and international capital (Iskander \& Chamlou, 2000). Corporate governance has become an international issue due to globalization of businesses. It is concerned with ways in which all parties involved in the well-being of the organization attempt to ensure that managers and other insiders take measures or adopt mechanisms that protect the interest of the stakeholders (Bulathsinhalage \& Pathirawasam, 2017).

The most comprehensive definition of corporate governance was provided by OECD (2004) as "the system by which business corporations are 
directed and controlled. The corporate governance structure specifies the distribution of rights and responsibilities among different participants in the corporation, such as the board, managers, shareholders and other stakeholders and spells out the rules and procedures for making decisions in corporate affairs" (OECD, 2004). Corporate governance can be also understood as the internal organization of the company - i.e. the composition of the supervisory board and the board of directors, and the relations between shareholders and management (Roubíček, 1998). Monks and Minow (2011) define corporate governance as relations between various stakeholders in influencing company's governance and performance, where primary stakeholders are shareholders and management, and secondary are employees, customers, suppliers, creditors, and other stakeholders.

OECD Principles became the basis for the creation of national codes of corporate governance in most developed countries. As the role of corporate governance practices is raising, new principles are developed to increase the effectiveness of corporate governance. OECD recently upgraded its principles for the 2nd time with the aim to increase the confidence of companies and investors in the capital market (OECD, 2015).

\subsection{Corporate governance and debt policy}

From the governance of corporation point of view, two contrasting roles of debt are highlighted by the authors. Firstly, debt is seen as a "disciplining device to contain agency problems between outside shareholders and managers" and, secondly, as a "mechanism of expropriation of minority shareholders and creditors by controlling insiders" (J. Sarkar \& S. Sarkar, 2008). The separation of ownership from management can result in information asymmetry, which leads to agency costs from the side of shareholders (Jensen \& Meckling, 1976). This information asymmetry has an influence on firms financing policy, where firms will prefer debt over equity not only because of the unattractiveness of equity caused by information asymmetry and the attribute of debt being less sensitive on information asymmetry problems (Myers \& Majluf, 1984), but also because of its property as an effective disciplining tool to restrain managerial ac- tions against maximization of shareholder value (Berger et al., 1997; Hart \& Moore, 1995; Jensen, 1986; Jensen \& Meckling, 1976). Faccio et al. (2001) add that the role of debt as a disciplining mechanism is weaker in corporations with concentrated ownership structures, where management is oftentimes drawn from among insider shareholders. On the other hand, the role of debt is more effective as a disciplining mechanism or as a mechanism for expropriation in countries with good institutional backgrounds. A well-developed banking system, accounting and audit system, effective bankruptcy and insolvency system, and an effective law enforcement system are necessary requirements for successful debt-based corporate governance (Day \& Taylor, 2004). J. Sarkar and S. Sarkar (2008) findings support the need for good institutional background. Their research was based on a large emerging economy, India, during the period of institutional change - i.e. the years 1996, 2000 and 2003. The disciplinary effect of debt appeared after the institutional changes, as the institutions shifted towards being more market-oriented.

\subsection{Equity vs debt}

In terms of choosing how to finance investment opportunities, companies have two options, namely debt or equity. Mande et al. (2011) found that companies with stronger corporate governance tend to prefer equity because of the effect of strong corporate governance itself on reducing agency costs. Furthermore, even smaller companies, which face more information asymmetry problems, tend to choose equity over debt. However, it is useful to note that their research was conducted within a well-developed equity market - i.e. on US equity and debt issuances. For the preference of equity over debt financing, there is a need for well-developed equity markets and the fostering of culture of saving, investment, and risk-taking (Day \& Taylor, 2004; Belas et al., 2018). Therefore, the results could be different in other markets.

The results could also vary among different corporate governance systems. For example, the Continental European system is well-known for its features such as (1) banks, companies and families are large shareholders and the ownership is concentrated; (2) relative illiquidity of the capital market; (3) banks playing a major role in corpo- 
rate governance (Cuervo, 2002). The high dependency on banks could lead to debt preference over equity, especially in the case of Slovakia, where the equity market is not that well-developed.

"It is generally better to issue safe securities than risky ones. Firms should go to the bond markets for external capital, but raise equity by retention if possible. That is, external financing using debt is better than financing by equity" (Myers \& Majluf, 1984). According to Ghouma et al. (2018), there are three advantages in debt financing: (1) tax shield benefits in the case of issuing debt; (2) the monitoring role of debt in high leveraged firms; and (3) debt might be a positive sign to the markets, what could lead to reducing asymmetric information between companies and investors.

Overall, is not recommended to use only one source of financing. Choosing the right capital structure can be very difficult. Firstly, it has to maximize the value of financing projects, and, secondly, it should also reflect the interests of managers, owners and creditors. Different interests between managers and owners could lead to information asymmetry. In the short term, debt can reduce the number of remunerations, if they are set on a profit-sharing system (Šuranová, Saxunová, \& Krištofík, 2009), which could lead to unhealthy equity preferences. Asymmetric information problems arise also between managers and creditors, which leads to a higher cost of debt and tighter nonprice debt terms (Rajan \& Winton, 1995).

\subsection{Corporate governance and indebtedness}

Several authors investigated the direct relationship between corporate governance and the indebtedness of companies. We can divide them into two groups based on the point of view of their research. The first group researched the overall impact of corporate governance on indebtedness (Chen et al., 2010; Funchal et al., 2008), whereas the second group's research was based on specific corporate governance areas and their impact on indebtedness (Wen et al., 2002; Peiró \& Gracia, 2016; Jiraporn \& Gleason, 2007; Berger et al., 2012). The results from the second group are mixed, so we can't outline any overall stance on corporate governance and indebtedness.

Funchal et al. (2008) researched the effect of corporate governance on loans variables as shortterm debt, long-term debt and the total indebtedness. The overall findings are that an improvement in corporate governance can increase the indebtedness of companies, whereas the most sensitive variables are the short-term debt and the total indebtedness. They also found the positive effect of corporate governance practices on lowering debt costs. Chen et al. (2010) add that the external financing needs provide incentives for firms to improve the overall quality of their corporate governance practices.

\subsection{Corporate governance and dividend policy}

According to Silva et al. (2004), there are three different uses of dividends in terms of corporate governance: (1) a managerial tool to signal the performance of the company to shareholders; (2) a monitoring tool for shareholders ${ }^{1}$; and (3) dividends are "hard cash" for shareholders and one of two ways (the other one is capital gains) of giving a return on investment for shareholders.

In the first case, dividends are seen as an alternative signaling device for managers who (1) tend to increase them when there is a high chance that future cash flows are sufficient or (2) tend to decrease them when there is a high chance that future cash flows won't be sufficient to sustain the actual pay-out rate. The announcements of dividend changes have a positive correlation with abnormal share price returns (Silva et al., 2004). However, Easterbrook (1984) thinks that there is no signaling role of dividends ${ }^{2}$, "unless the cost of issuing dividends is uniformly lower for prosperous firms". In either case, if managers do not act as perfect agents of shareholders, then it can induce the need for monitoring and cause agency costs.

1 For theoretical and empirical evidence, see Silva et al. (2004)

2 Dividend pay-outs can't distinguish well-managed, prospering firms from others. Prosperous firms may choose not to pay dividends and use them instead as an internal form of financing, which is undoubtedly cheaper compared to issuing dividends and floating new securities. On the other hand, poorly managed or failing firms are recommended to disinvest or liquidate, and dividend pay outs are one option of accomplishing this (Eastbrook, 1984). 
Easterbrook (1984) provides a good example of the monitoring role of dividends: "Suppose a firm has an initial capitalization of 100 , of which 50 is debt and 50 is equity. It invests the capitalization of 100 in a project. The firm prospers, and earnings raise its holdings to 200 . The creditors now have substantially more security than they started with, and correspondingly the residual claimants are paying the creditors a rate of interest unwarranted by current circumstances. They can correct this situation by paying a dividend of 50 while issuing new debt worth 50 . The firm's capital continues to be 200, but the debate-equity ratio has been restored, and the interest rate on the original debt is again appropriate to the creditors' risk".

Another point of view on dividend policy came from the agency theory. La Porta et al. (2000) in their work proposed two models: "the outcome model" and "the substitution model". "The outcome model" predicts higher dividend pay-outs from firms with better corporate governance and stronger shareholder rights. The logic behind it is that by paying dividends, shareholders restrict management from using the excess cash on their own private benefits. "The substitution model" predicts the opposite, i.e. firms with weaker corporate governance practices and weaker shareholder rights will pay higher dividends as a substitution of poor governance or as a compensation for weak shareholders' rights. By doing so, they attempt to establish a good reputation in the market (Jiraporn \& Ning, 2006) and maintain good relationships with shareholders (La Porta et al., 2000).

\subsection{Corporate governance and dividend payouts}

Adjaoud and Amar (2010) investigated the direct impact of corporate governance quality on dividend pay-outs on the sample of 714 companies listed on the Toronto Stock Exchange over the period 2002-2005. It was found that companies with stronger corporate governance paid higher dividends. Out of 4 components of their corporate governance index, the board composition and shareholder rights' policy were the most influencing variables on dividend pay-outs. Chang and Dutta (2012) came to the same conclusion on a set of Canadian firms over the period 1997-2004. However, they didn't compound a corporate gov- ernance index, instead, they used the number of board members as a measurement for corporate governance. The positive impact of stronger corporate governance on dividend pay-outs was also confirmed by Francis et al. (2011), Jiraporn et al. (2011), Musa et al. (2015).

La Porta et al.'s (2000) cross country research based on the sample of 33 countries found support for "the outcome model". Moreover, they found that fast growth firms pay lower dividends than slow growth firms, which is, as they add, is consistent with the idea that strong shareholder protection is inducing the willingness to wait for dividends when investment opportunities are good.

On the other hand, recent research by Chang et al. (2018) analyzed the effect of corporate governance on dividend payout policy on a large sample of firms from 30 countries. They confirmed that firms with stronger corporate governance tend to pay more dividends, even after controlling for country-level governance. However, this is true only in countries with low shareholder rights, which is consistent with "the substitution model". Jiraporn and Ning (2006) investigated the impact of shareholder rights on dividend policy in the case of United States of America, where they used the IRRC (The Investor Responsibility Research Center) corporate governance database. Companies with weaker shareholder rights paid higher dividends. They argue that this may be the result of the high level of market development, which provides better monitoring, and, thus, there is a stronger need for favorable reputation in order to raise capital on better terms.

\section{DATA AND METHODOLOGY}

The presented study examines the impacts of corporate governance implementation on the debt and dividend policies in companies in Slovakia. The main aim of the study is to present the outcomes of research, which focused on the investigation of correlations between the responsible application of corporate governance principles and the indebtedness and dividend pay-outs in selected companies.

The subjects of our research were all the corporations listed on the Bratislava Stock Exchange from 
2015 to 2017, what counts for 61,59 and 59 corporations, respectively. The aim of our research is to determine if there is a relationship and, if yes, to what extent, between our Corporate Governance Index and the indebtedness, and Corporate Governance Index and the dividend pay-outs. Because of the absence of the normal distribution, Spearman's rank correlation coefficient was used to evaluate the collected data.

Based on the secondary data analysis and reported studies results, we set the following hypotheses:

H1: We assume that there is a correlation between the level of corporate governance in corporations listed on the Bratislava Stock Exchange and their indebtedness.

H2: We assume that there is a correlation between the level of corporate governance in companies listed on Bratislava Stock Exchange and the dividend pay-outs.

In the first part of our analysis, we conducted an extensive survey of disclosure in corporate governance, where the information was obtained from the corporation's annual financial reports available either in the Central Register of Regulated Information or on the corporation's websites, or both. Then, we measured the level of corporate governance using the method presented in a previous research by Musa et al. (2014). In short, we conducted a Corporate Governance Index using the data from our observations. The Index uses ordinal measures of various evaluative criteria. Appendices A, B and C present the criteria and also the results for the observed period.

The second part was to create our Corporate Governance Index for each monitored corporation. The weighting of each criterion in the Index is as follows (for information about each criterions see Appendices A, B and C):

$$
\begin{aligned}
& C G_{\text {index }}=1.2 x(1)+(2)+2 x(3)+ \\
& +(4)+(5)+(6)+(7 a)+(7 b)+(7 c) .
\end{aligned}
$$

In the case of indebtedness of corporations, we decided to follow Funchal et al.'s (2008) methodology, where he measured the impact of corporate governance on short-term, long-term and total in- debtedness. The formula for evaluating the indebtedness of the corporations is as follows:

$$
\text { Debt }_{\text {ratio }}=\frac{\text { Intermediated debt }}{\text { Total assets }} .
$$

In the case of dividend pay-outs, we couldn't use the Dividend per Share ratio because of the weak dividend policy among corporations listed on Bratislava Stock Exchange. Also, the number of companies paying dividend was low (10, 8 and 10 corporations in 2015, 2016 and 2017, respectively). Instead, we used a dummy variable, which presents whatever the company paid dividends or did not.

The last step was adjusting the data for each case. In the case of indebtedness, we removed banks and insurance corporations because of their specific approach to loans. Bank and insurance companies have specific business models, which do not have to necessarily include intermediated debt. Furthermore, banks are intermediaries on the loan market, they usually do not use loans to the extent of other market participators. Furthermore, we noticed that approximately $50 \%$ of the companies are not using any debt, therefore, we adjusted the already adjusted data further and removed companies without debt. We believe that debt is a necessary tool, which should be used by every company. By not using debt, companies are losing opportunities for further expansion, projects and growth overall.

In the case of the 2nd hypothesis, we conducted our analysis with the whole data set first and then without the corporations, which ended the year with a loss, so we could measure more precisely the impact of Corporate Governance Index on the choice of dividend pay-outs. After all, corporations with a loss have limited options of paying dividends.

\section{EMPIRICAL RESULTS AND DISCUSSION}

Based on the value of the Spearman's coefficient, it is evident that a correlation is present between the level of our Corporate Governance Index and the indebtedness every year. Overall, the strongest correlation was present in long-term indebted- 
ness, then in total indebtedness and the weakest in short-term indebtness. All of the coefficients were statistically relevant, however, some of them only at 0.1 level. Looking closer on the outcome of our analysis, we can note a decreasing trend in the sensitivity of the Corporate Governance Index on the long-term and total indebtedness, i.e. with increasing levels of Corporate Governance Index, the long-term and total indebtedness decreased, and vice versa for the short-term indebtedness.

It is also worth noting that the adjustment of the data had a major impact on our analysis. Banks and insurance corporations from our data had overall high levels of the Corporate Governance Index and low level of indebtedness, which means they would lower the significance level of our model, as well as Spearman's coefficient.

Table 1. Correlations between corporate governance index and debt (the case of first adjustment)

\begin{tabular}{|c|c|c|c|c|}
\hline Year & Type of dept & $\begin{array}{c}\text { Spearman's } \\
\text { Rho }\end{array}$ & $P$-value & $\mathbf{N}$ \\
\hline \multirow{3}{*}{2015} & $\begin{array}{c}\text { Short-term } \\
\text { debt }\end{array}$ & 0.250 & 0.087 & 48 \\
\hline & $\begin{array}{l}\text { Long-term } \\
\text { debt }\end{array}$ & 0.515 & $0^{* *}$ & 48 \\
\hline & Total debt & 0.409 & $0.004 * *$ & 48 \\
\hline \multirow{3}{*}{2016} & $\begin{array}{c}\text { Short-term } \\
\text { debt }\end{array}$ & 0.259 & 0.082 & 46 \\
\hline & $\begin{array}{l}\text { Long-term } \\
\text { debt }\end{array}$ & 0.326 & $0.027^{*}$ & 46 \\
\hline & Total debt & 0.269 & 0.070 & 46 \\
\hline \multirow{3}{*}{2017} & $\begin{array}{c}\text { Short-term } \\
\text { debt }\end{array}$ & 0.360 & $0.012^{*}$ & 48 \\
\hline & $\begin{array}{c}\text { Long-term } \\
\text { debt }\end{array}$ & 0.255 & 0.080 & 48 \\
\hline & Total debt & 0.329 & $0.022^{*}$ & 48 \\
\hline
\end{tabular}

Note: ${ }^{*}$ Correlation is significant at the 0.05 level (2-tailed), ** correlation is significant at the 0.01 level (2-tailed).

Table 2 presents the results of the 2nd adjustment, i.e. not only banks and insurance companies where removed, but also companies without debt. As we can see, Spearman's Rho is statistically relevant only in 3 cases, where, compared to the 1st adjustment, the results suggest a bit weaker correlation.

At this point, the results can appear more chaotic, but owing to it we actually proved that companies with zero debt have a tendency towards having lower values of Corporate Governance Index. To be more precise, by proving a positive correlation between Corporate Governance Index and the indebtedness of the 1st adjusted data and at the same time by failing to prove a correlation in the case of the 2 nd adjustment, we proved that already the decision of whenever to use debt or not is affected by the level of Corporate Governance Index, i.e. corporations with lower levels of Corporate Governance Index tend not to use debt at all.

Table 2. Correlations between Corporate Governance Index and indebtedness (2nd adjustment)

\begin{tabular}{|c|c|c|c|c|}
\hline Year & Type of debt & $\begin{array}{c}\text { Spearman's } \\
\text { Rho }\end{array}$ & $P$-value & $\mathbf{N}$ \\
\hline \multirow{3}{*}{2015} & $\begin{array}{c}\text { Short-term } \\
\text { debt }\end{array}$ & -0.282 & 0.163 & 26 \\
\hline & Long-term debt & 0.459 & $0.018^{*}$ & 26 \\
\hline & Total debt & 0.124 & 0.546 & 26 \\
\hline \multirow{3}{*}{2016} & $\begin{array}{c}\text { Short-term } \\
\text { debt }\end{array}$ & 0.168 & 0.384 & 29 \\
\hline & Long-term debt & 0.334 & 0.077 & 29 \\
\hline & Total debt & 0.235 & 0.22 & 29 \\
\hline \multirow{3}{*}{2017} & $\begin{array}{c}\text { Short-term } \\
\text { debt }\end{array}$ & 0.339 & 0.067 & 30 \\
\hline & Long-term debt & 0.171 & 0.366 & 30 \\
\hline & Total debt & 0.305 & 0.101 & 30 \\
\hline
\end{tabular}

Note: * Correlation is significant at the 0.05 level (2-tailed).

Table 3 presents the results for the 2 nd hypothesis in both cases, namely adjusted and non-adjusted data set. For the year 2015, we found no correlation between dividend pay-outs and the level of our Corporate Governance Index. However, in the following years, a relative weak positive correlation is present, as all of our Spearman's Rho are statistically relevant. The strongest correlation was present in 2016, where the data set of all companies had a Spearman's coefficient of 0.289 and the data set of only profitable companies had a Spearman's coefficient of 0.331 .

Furthermore, if we compare the results between the data sets, we will notice a stronger correlation in the case of profitable companies compared to the case of all companies. The reasons behind it are (1) that profitable corporations with higher levels of Corporate Governance Index have a higher tendency towards paying dividends than corporations with lower levels of Corporate Governance Index, and (2) that corporations which presented 
a loss do not necessarily tend to have lower levels of Corporate Governance Index. The latest point is proved by a weaker intensity in the case of the data set with all companies, compared to only profitable companies.

Table 3. Correlations between Corporate Governance Index and dividend pay-outs

\begin{tabular}{c|c|c|c|c}
\hline \multirow{2}{*}{ Year } & $\begin{array}{c}\text { Dividend } \\
\text { pay-outs }\end{array}$ & $\begin{array}{c}\text { Spearman's } \\
\text { Rho }\end{array}$ & P-value & N \\
\hline \multirow{2}{*}{2015} & All companies & 0.176 & 0.195 & 57 \\
& Only profitable & 0.118 & 0.476 & 39 \\
\multirow{3}{*}{2016} & All companies & 0.289 & $0.03^{*}$ & 56 \\
& Only profitable & 0.331 & $0.043^{*}$ & 38 \\
\multirow{2}{*}{2017} & All companies & 0.262 & 0.053 & 55 \\
& Only profitable & 0.292 & 0.089 & 35 \\
\hline
\end{tabular}

Note: *. Correlation is significant at the 0.05 level (2-tailed).

\section{DISCUSSION}

Previous research was done in 2012 by Musa et al. (2014) who found that there is a positive correlation between the level of corporate governance and the total indebtedness of companies. Their Spearman's coefficient had a value of 0.328 , which suggests a relatively weak positive correlation. Their research was based only on total indebtedness, therefore, a comparison can be made only at this level. Our Spearman's coefficient is approximately at the same levels with small differences. However, it is worth noting that our dataset is adjusted and their is not. The adjustment of data had an overall positive impact on the results. As we outlined it before, banks and insurance companies removed from the data set have naturally low levels of debt and higher levels of corporate governance. The reasons are: (1) banks are intermediaries on the debt market, they do not tend to use normally debt in the same amount as other companies, because their business is built on capital allocation; (2) the same goes for insurance companies, their business model is not based on debt but on money allocation from a pool of insurance payments to the insurer who's insurance claims were approved; (3) because of higher risk the companies are exposed to, appropriate risk management and relevant information disclosure are necessary requirements of investors.
Furthermore, we also proved a positive relationship between our Corporate Governance Index and the short-term, long-term and total indebtedness of companies. The long-term and total indebtedness has a tendency to decrease in the following years, whereas the short-term indebtedness shows a tendency to increase. Also, the levels of short-term indebtedness seem to be low compared to long-term indebtedness, because their reverse effect was not strong enough to affect the total indebtedness.

To sum it up, we did not only proved (1) that levels of corporate governance have positive correlation with the various levels of indebtedness, but also (2) that the choice of whenever to use debt or not is already influenced by the level of corporate governance.

In the case of the second hypothesis, whenever there is a correlation between the level of corporate governance and dividend pay-outs, the results are weaker compared to Musa et al. (2014) who present a relatively low positive correlation, with Spearman's coefficient value of 0.386 . In 2015, we did not found any correlation, but for 2016 and 2017, there is 0.289 and 0.262 correlation, respectively. It appears that the correlation between those to variables tend to further decrease in time, suggesting the lowering impact of corporate governance on dividend pay-outs. However, after the adjustment, it seems that the correlation got stronger.

The reason for the adjustment was to remove companies with a loss, so the model would consist only of companies that presented a profit. It is a wellknown fact that companies with a loss have overall limited options of paying dividends. Thanks to the adjustment, we actually proved that the relationship between corporate governance and dividend payouts is even stronger. To be more precise, our results showed (1) that profitable corporations with higher levels of Corporate Governance Index have higher tendency towards paying dividends than corporations with lower levels of Corporate Governance Index, and (2) that corporations with a presented loss do not necessarily tend to have lower levels of Corporate Governance Index.

It is worth noting that those results could be achieved only by the relevant adjustment of datasets. Looking at the same problem from different perspectives can result in a more complex and more precise outcome. 


\section{CONCLUSION}

In this paper, we examined how corporate governance can influence the debt and dividend policies, since, different companies have different level of corporate governance practices. We hypothesized that (1) corporate governance can influence the level of indebtedness and (2) the dividend pay-outs in corporations listed on Bratislava Stock Exchange for the years of 2015, 2016 and 2017. Our dataset had 61, 59 and 59 corporations, respectively, however, for the higher accuracy we adjusted the data. In the first case we removed banks and insurance companies. In the case of dividend pay-outs, first, we used the whole data set and then removed the companies, which presented a loss.

In the case of indebtedness, we assumed that there is a correlation between our Corporate Governance Index and the indebtedness of corporations. We found that there is a positive correlation between the level of corporation's corporate governance and their indebtedness on every level. The Spearman's coefficient further indicates a relatively weak correlation. A previous research was done in Slovakia in 2012 by Musa et al. (2014) and their findings support ours.

The second hypothesis investigated the relationship between our Corporate Governance Index and the dividend pay-outs. In the year 2015, we found no correlation, however, in the following years, our results support a positive, relatively weak correlation between those variables. Also, it appears that good corporate governance practises affect companies' dividend policy even more. Out of the profitable companies, only those with higher levels of Corporate Governance Index have a tendency to pay dividends, and those with a presented loss do not necessarily tend to have lower levels of Corporate Governance Index. Musa et al. (2014) found approximately the same levels of correlation for the year 2012, however, with non-adjusted data.

\section{ACKNOWLEDGEMENT}

This paper has been supported by the Scientific Grant Agency of Slovak Republic under project VEGA No. 1/0749/18 "Research on the application of corporate governance principles in companies in Slovakia".

\section{REFERENCES}

1. Adjaoud, F., \& Amar, W. B. (2010). Corporate Governance and Dividend Policy: Shareholders' Protection or Expropriation? Journal of Business Finance \& Accounting, 37(5-6), 648-667. https://doi.org/10.1111/j.14685957.2010.02192.x

2. Belas, J., Dvorsky, J., Kubalek, J., \& Smrcka, L. (2018). Important factors of financial risk in the SME segment. Journal of International Studies, 11(1), 80-92. https://doi. org/10.14254/2071-8330.2018/11$1 / 6$

3. Berger, P. G., Oferk, E., \& Yermack, D. L. (1997). Managerial entrenchment and capital structure decisions. The Journal of Finance, 52(4) 1411-1438. https:// doi.org/10.1111/j.1540-6261.1997. tb01115.x.

4. Blendinger, G., \& Michalski, G. (2018). Long-term competitiveness based on value added measures as part of highly professionalized corporate governance management of German DAX30 corporation. Journal of Competitiveness, 10(2), 5-20. https://doi.org/10.7441/ joc.2018.02.01

5. Bulathsinhalage, S., \& Pathirawasam, Ch. (2017). The Effect of Corporate Governance on Firms Capital Structure of Listed Companies in Sri Lanka. Journal of Competitiveness, 9(2), 19-33. https://doi.org/10.7441/ joc.2017.02.02
6. Chang, B., \& Dutta, S. (2012). Dividends and Corporate Governance: Canadian Evidence. IUP Journal of Applied Finance, 18(4), 5-30. Retrieved from https:// papers.ssrn.com/sol3/papers. cfm?abstract_id=2184699

7. Chang, B., Dutta, S., Saadi, S., \& Zhu, P. (2018). Corporate Governance and Dividend Payout Policy: Beyond country-level Governance. The Journal of Financial Research, 41(4), 445-484. https://papers.ssrn.com/sol3/papers.cfm?abstract_id=2994960

8. Chen, W., Chung, H., Hsu, T., \& $\mathrm{Wu}$, S. (2010). External financing needs, Corporate Governance and firm value. Corporate Governance: An international review, 18(3), 
234-249. https://doi.org/10.1111/ j.1467-8683.2010.00801.x

9. Cuervo, A. (2002). Corporate Governance Mechanisms: a plea for less code of good governance and more market control. Corporate Governance an International Review, 10(2), 84-93. https://doi.org/10.1111/14678683.00272

10. Day, J., \& Taylor, P. (2004). Institutional change and debtbased corporate governance: A comparative analysis of four transition economies. Journal of Management and Governance, 8(1), 73-115. Retrieved from https:// link.springer.com/article/10.1023/ B:MAGO.0000015394.71661.56

11. Easterbrook, F. (1984). Two agency-cost explanations of dividends. American Economic Review, 74(4), 650-659. Retrieved from https://www.jstor.org/ stable/1805130?seq=1\#page_scan_ tab_contents

12. Elbadry, A. (2010). Corporate Governance and Asymmetric Information (284 p.). Germany: VDM Verlag Dr. Muller GmBH.

13. Faccio, M., Lang, L. H. P., \& Young, L. (2001). Debt and corporate governance (Working Paper). The Chinese University of Hong Kong. Retrieved from http:// mba.vanderbilt.edu/fmrc/Activity/ paper/Faccio_Paper_Debt.pdf

14. Francis, B. B., Hassan, I., John, K., \& Song, L. (2011). Corporate Governance and Dividend Payout Policy: A Test Using Antitakeover Legislation. Financial Managment, 40(1), 83-112. https://doi.org/10.1111/j.1755053X.2010.01135.X

15. Funchal, B., Galdi, F. C., \& Lopes, A. B. (2008). Interactions between Corporate Governance, Bankruptcy law and firms debt financing: the Brazilian case. Brazilian Administration Review, 5(3), 245-259. http:// dx.doi.org/10.1590/S180776922008000300006

16. Ghouma, H., Nasr, H. B., \& Yan, R. (2018). Corporate governance and cost of debt financing: Empirical evidence from Canada. The
Quarterly Review of Economics and Finance, 67, 138-148. https:// do.org/10.1016/j.qref.2017.06.004

17. Hart, O., \& Moore, J. (1995). Debt and seniority: An analysis of the role of hard claims in constraining management. American Economic Review, 85(3), 567-585. Retrieved from https://www.jstor.org/ stable/2118188?seq=1\#page_scan_ tab_contents

18. Iskander, M. R., \& Chamlou, N. (2000). Corporate Governance: A Framework for Implementation. World Bank Group, Washington: D.C. https://doi.org/10.1596/08213-4741-1

19. Jensen, M. C. (1986). Agency costs of free cash flow, corporate finance, and takeovers. American Economic Review, 76, 323-329. Retrieved from https://www.jstor. org/stable/1818789?seq=1\#page_ scan_tab_contents

20. Jensen, M. C., \& Meckling, W. H. (1976). Theory of the firm: Managerial behavior, agency costs and ownership structure. Journal of Financial Economics, 3(4), 305360. https://doi.org/10.1016/0304405X(76)90026-X

21. Jiraporn, P., \& Gleason, K. C. (2007). Capital Structure, Shareholder Rights, And Corporate Governance. The Journal of Financial Research, 30(1), 21-33. Retrieved from https://papers.ssrn.com/sol3/papers.cfm?abstract_id=792604

22. Jiraporn, P., \& Ning, Y. (2006). Dividend Policy, Shareholder Rights, and Corporate Governance. https:// dx.doi.org/10.2139/ssrn.931290

23. Jiraporn, P., Kim, J. Ch., \& Kim, Y. S. (2011). Dividend Payouts and Corporate Governance Quality: An Empirical Investigation. The Financial Review, 46(2), 251-279. https://doi.org/10.1111/j.15406288.2011.00299.x

24. Kliestik, T., Michalkova, L., \& Kovacova, M. (2018). Is a tax shield really a function of net income, interest rate, debt and tax rate? Evidence from Slovak companies. Journal of International Studies, 11(4), 295-311. https://doi. org/10.14254/2071-8330.2018/11$4 / 21$

25. La Porta, R., Lopez De Salinas, F., Shleifer, A., \& Vishny, R. (2000). Agency problems and dividend policy around the world. Journal of Finance, 55(1), 1-33. https://doi. org/10.1111/0022-1082.00199

26. Mande, V., Park, Y. K., \& Son, M. (2011). Equity or Debt Financing: Does Good Corporate Governance Matter? Corporate Governance an International Review, 20(2), 195-211. https:// doi.org/10.1111/j.14678683.2011.00897.x

27. Monks, R. A. G., \& Minow, N (2011). Corporate governance. John Wiley \& Sons.

28. Mura, L., Haviernikova, K., \& Machova, R. (2017). Empirical results of entrepreneurs' network: Case study of Slovakia. Serbian Journal of Management, 12(1), 121-131. https://doi.org/10.5937// sjm12-10418

29. Musa, H., Musova, Z., \& Debnarova, L. (2015).

Responsibility in the Corporate Governance Framework and Financial Decision Making Process. Procedia Economics and Finance, 23, 1023-1029. https://doi.org/10.1016/S22125671(15)00371-8

30. Musa, H., Musova, Z., \& Debnárová, L. (2018). Importance of Corporate Governance in Socially Responsible Behaviour of Enterprises. Entrepreneurship - Development Tendencies and Empirical Approach. Retrieved from https://www.intechopen. com/books/entrepreneurshipdevelopment-tendenciesand-empirical-approach/ importance-of-corporate-governance-in-socially-responsiblebehaviour-of-enterprises

31. Myers, S. C., \& Majluf, N. S. (1984). Corporate financing and investment decisions when firms have information that investors do not have. Journal of Financial Economics, 13(2), 187-221. https://doi.org/10.1016/0304405X(84)90023-0

32. OECD (2004). G20/OECD Principles of Corporate Governance. 
Retrieved from http://www.oecd. org/daf/ca/corporategovernanceprinciples/31557724.pdf

33. OECD. (2015). G20/OECD Principles of Corporate Governance. Retrieved from https://www.oecd.org/daf/ca/Corporate-Governance-PrinciplesENG.pdf

34. Peiró, N. G., \& Gracia, J. L. (2016). Corporate Governance and Capital Structure: A Spanish Study. European Management Review, 14(1), 33-45. https://doi. org/10.1111/emre.12088

35. Rajan, R. G., \& Winton, A. (1995). Covenants and collateral as incentives to monitor. Journal of Finance,
50(4), 1113-1146. https://doi. org/10.1111/j.1540-6261.1995. tb04052.x

36. Roubíček, L. (1998). Corporate governance. Ostrava: VSB Technická univerzita.

37. Sarkar, J., \& Sarkar, S. (2008). Debt and corporate governance in emerging economies Evidence from India. Economics of Transition and Institutional Change, 16(2), 293-334. https:// doi.org/10.1111/j.14680351.2008.00307.x

38. Silva, L. C., Goergen, M., \& Renneboog, L. (2004). Dividend Policy and Corporate Governance. New York: Oxford University Press.
39. Šuranová, Z., Saxunová, D., \& Krištofík, P. (2009). Finančné účtovníctvo a riadenie s aplikáciou IAS/IFRS (767 p.). Bratislava: Iura Edition. Retrieved from https:// books.google.com.ua/books/ about/Finan\%C4\%8Dn\%C3\% A9_\%C3\%BA\%C4\%8Dtovn\%C 3\%ADctvo_a_riadenie_s_a.ht$\mathrm{ml}$ ?id=iDOWGAAACAAJ\&redir esc $=\mathrm{y}$

40. Wen, Y., Rwegasira, K., \& Bilderbeek, J. (2002). Corporate Governance and Capital Structure Decisions of the Chines Listed Firms. Corporate Governance an International Review, 10(2), 75-83. https://doi. org/10.1111/1467-8683.00271

\section{APPENDIX A}

Table A1. Evaluation of 1st, 2nd, 3rd and 4th criteria and results

Source: Authors' results.

\begin{tabular}{|c|c|c|c|}
\hline Criteria & Description & Ordinal scale & $\begin{array}{c}\text { Results - numbers } \\
\text { of companies } \\
2015 / 2016 / 2017\end{array}$ \\
\hline \multirow{3}{*}{$\begin{array}{l}\text { 1. Disclosure } \\
\text { of annual report }\end{array}$} & \multirow{3}{*}{$\begin{array}{l}\text { Availability of information to shareholders } \\
\text { and potential investors, such as annual } \\
\text { financial report, annual report, a statement on } \\
\text { corporate governance and other information } \\
\text { that goes beyond legal obligations }\end{array}$} & “0" - annual report is not disclosed & $0 / 0 / 0$ \\
\hline & & $\begin{array}{l}\text { "1" - annual report is published in the } \\
\text { CERI or on the company's website }\end{array}$ & $13 / 13 / 10$ \\
\hline & & $\begin{array}{l}2 " \text { - annual report is published in the CERI } \\
\text { and company's website }\end{array}$ & $44 / 43 / 45$ \\
\hline \multirow{3}{*}{ 2. Annual report } & \multirow{3}{*}{$\begin{array}{l}\text { The scope and clarity of the information about } \\
\text { corporate governance in an annual report }\end{array}$} & $\begin{array}{l}\text { "0" - annual report does not contain } \\
\text { information about corporate governance }\end{array}$ & $10 / 6 / 7$ \\
\hline & & $\begin{array}{l}\text { "1" - annual report contains partial } \\
\text { information about corporate governance }\end{array}$ & $40 / 40 / 38$ \\
\hline & & $\begin{array}{l}\text { "2" - annual report contains partial } \\
\text { information about corporate governance } \\
\text { and deviations from the Code }\end{array}$ & $7 / 10 / 10$ \\
\hline \multirow{3}{*}{$\begin{array}{l}\text { 3. Statement } \\
\text { on corporate } \\
\text { governance }\end{array}$} & \multirow{3}{*}{ The scope, clarity and quality of information } & $\begin{array}{l}\text { " } 0 \text { " - the statement is not available or } \\
\text { does not contain any specific information }\end{array}$ & $30 / 28 / 28$ \\
\hline & & $\begin{array}{l}\text { "1" - includes a brief explanation of each } \\
\text { point of the statement }\end{array}$ & $7 / 8 / 6$ \\
\hline & & $\begin{array}{l}\text { " } 2 \text { " - contains explanations of each } \\
\text { point of the statement and reasons for } \\
\text { deviations from the Code }\end{array}$ & $20 / 20 / 21$ \\
\hline \multirow{3}{*}{$\begin{array}{l}\text { 4. Boards } \\
\text { of companies }\end{array}$} & \multirow{3}{*}{$\begin{array}{l}\text { Disclosure of information about board } \\
\text { members, such as names, experience, } \\
\text { responsibility and functions }\end{array}$} & "O" - no information & $3 / 1 / 1$ \\
\hline & & "1" - only the names of board members & $46 / 45 / 42$ \\
\hline & & $\begin{array}{l}\text { "2" - the names of board members, } \\
\text { together with the qualifications, roles } \\
\text { and responsibilities and management } \\
\text { functions }\end{array}$ & $8 / 10 / 12$ \\
\hline
\end{tabular}




\section{APPENDIX B}

Table B1. Evaluation of 5th and 6th criteria and results

Source: Authors' results.

\begin{tabular}{|c|c|c|c|}
\hline Criteria & Description & Ordinal scale & $\begin{array}{l}\text { Results - numbers } \\
\text { of companies }\end{array}$ \\
\hline \multirow{3}{*}{$\begin{array}{l}\text { 5. Remuneration } \\
\text { of board } \\
\text { members }\end{array}$} & \multirow{3}{*}{$\begin{array}{l}\text { Information about the structure } \\
\text { and amount of remuneration for } \\
\text { individual members of the board }\end{array}$} & "0" - no information & $33 / 36 / 33$ \\
\hline & & $\begin{array}{l}\text { "1" - only cumulative information about } \\
\text { remuneration }\end{array}$ & $22 / 18 / 19$ \\
\hline & & $\begin{array}{l}\text { "2" - information about the amount of remuneration } \\
\text { of individual board members }\end{array}$ & $2 / 2 / 3$ \\
\hline \multirow{3}{*}{$\begin{array}{l}\text { 6. Risk } \\
\text { management }\end{array}$} & \multirow{3}{*}{$\begin{array}{l}\text { Information about risk } \\
\text { management, defined predictable } \\
\text { risks and risk quantification }\end{array}$} & "O" - no specific information & $29 / 25 / 25$ \\
\hline & & $\begin{array}{l}\text { "1" - basic information about risk management and } \\
\text { defined predictable risks }\end{array}$ & $6 / 10 / 8$ \\
\hline & & $\begin{array}{l}\text { "2" - comprehensive information about risk } \\
\text { management and risk quantification }\end{array}$ & $22 / 21 / 22$ \\
\hline
\end{tabular}

\section{APPENDIX C}

Table C1. Evaluation of the 7th (7a, 7b, 7c) criteria and results

\begin{tabular}{|c|c|c|c|}
\hline Criteria & Description & Ordinal scale & $\begin{array}{l}\text { Results - numbers } \\
\text { of companies }\end{array}$ \\
\hline \multirow{3}{*}{$\begin{array}{l}\text { 7a. Audit } \\
\text { Committee }\end{array}$} & \multirow{3}{*}{$\begin{array}{l}\text { Information about the } \\
\text { establishment or failure to } \\
\text { establish committees and their } \\
\text { activities }\end{array}$} & "0" - no information & $14 / 11 / 7$ \\
\hline & & $\begin{array}{l}\text { "1" - information about the establishment or failure } \\
\text { to establish committee }\end{array}$ & $24 / 26 / 32$ \\
\hline & & $\begin{array}{l}\text { " } 2 \text { " - in the case of establishing of the committees } \\
\text { there is an information about the activities and results } \\
\text { of the committees }\end{array}$ & $19 / 19 / 17$ \\
\hline \multirow{3}{*}{$\begin{array}{l}\text { 7b. Remuneration } \\
\text { Committee }\end{array}$} & \multirow{3}{*}{$\begin{array}{l}\text { Information about the } \\
\text { establishment or failure to } \\
\text { establish committees and their } \\
\text { activities }\end{array}$} & “ 0 " - no information & $39 / 38 / 39$ \\
\hline & & $\begin{array}{l}\text { "1" - information about the establishment or failure } \\
\text { to establish committee }\end{array}$ & $13 / 12 / 11$ \\
\hline & & $\begin{array}{l}\text { " } 2 \text { " - in the case of establishing of the committees } \\
\text { there is an information about the activities and results } \\
\text { of the committees }\end{array}$ & $5 / 6 / 5$ \\
\hline \multirow{3}{*}{$\begin{array}{l}\text { 7c. Nomination } \\
\text { Committee }\end{array}$} & \multirow{3}{*}{$\begin{array}{l}\text { Information about the } \\
\text { establishment or failure to } \\
\text { establish committees and their } \\
\text { activities }\end{array}$} & "0" - no information & $41 / 41 / 41$ \\
\hline & & $\begin{array}{l}\text { "1" - information about the establishment or failure } \\
\text { to establish committee }\end{array}$ & $14 / 13 / 12$ \\
\hline & & $\begin{array}{l}\text { " } 2 \text { " - in the case of establishing of the committees } \\
\text { there is an information about the activities and results } \\
\text { of the committees }\end{array}$ & $2 / 2 / 2$ \\
\hline
\end{tabular}

